\title{
Two-stage heat pumps for energy saving technologies
}

\author{
A. E. Denysova ${ }^{凶}$, G. V. Luzhanska, I. O. Bodnar, A. S. Denysova \\ Odessa National Polytechnic University, av.Shevchenko, 1, Odessa, 65044, Ukraine \\ $\triangle$ e-mail: alladenysova@gmail.com
}

The problem of energy saving becomes one of the most important in power engineering. It is caused by exhaustion of world reserves in hydrocarbon fuel, such as gas, oil and coal representing sources of traditional heat supply. Conventional sources have essential shortcomings: low power, ecological and economic efficiencies that can be eliminated by using alternative methods of power supply, like the considered one: low-temperature natural heat of ground waters on the basis of heat pump installations application. The considered heat supply system provides an effective use of two stages heat pump installation operating as heat source at ground waters during the lowest ambient temperature period. The calculation method of heat pump installations on the basis of groundwater energy is proposed. The values of electric energy consumption by the compressors' drive, and the heat supply system transformation coefficient $\mu$ for a low-potential source of heat from ground waters allowing to estimate high efficiency of two stages heat pump installations are calculated.

Keywords: Heating Loading; Freon; Two Stages Heat Pump Installation; Low-Potential Source of Heat; Energy Efficiency

\section{Двоступеневі теплонасосні установки для енергозберігаючих технологій}

\section{А. Є. Денисова, Г. В. Лужанська, І. О. Боднар, А. С. Денисова}

Одеський національний політехнічний університет, пр. Шевченка, 1, Одеса, 65044, Україна

\begin{abstract}
Одним з основних напрямків вдосконалення систем теплопостачання є тенденція переходу на низькотемпературні системи опалення на основі теплонасосних установок. Запропоновано методику розрахунку теплонасосних установок на базі грунтових вод. Розроблено алгоритм розрахунку теплонасосної установки, реалізація якої підтверджує ефективність ї̈ роботи для теплопостачання споживачів. Встановлено раціональну глибину i кількість свердловин, які забезпечують надійну роботу теплонасосних систем при мінімальній потужності електроприводу насосів, щзо подають грунтову воду до теплонасосної установки. Встановлено, щчо раціональне розміщення трьох менших за глибиною свердловин в порівнянні з однієї свердловиною дозволяє заощадити витрата електроенергії в 1,7 разів. Шляхом числового моделювання теплових процесів в елементах одноступінчатої і двоступеневої теплонасосних установок встановлено, щзо більш ефективною є двоступенева теплонасосна установка для системи опалення «тепла підлога». Це досягається за рахунок більш низької температури теплоносія, щуо подається під внутрібудинкову систему, внаслідок чого для досягнення комфортних температурних режимів потрібно менше електроенергї на привід компресора. Визначено коефіцієнти трансформаціі теплоти, потужність, споживана електроприводом компресора теплового насоса. Виконано оцінку ефективності використання запропонованих теплонасосних систем для заданих кліматичних умов і встановлені умови ефективного використання теплонасосних систем на базі грунтових вод.
\end{abstract}

Ключові слова: теплонасосна установка; грунтова вода; утилізація; низькопотенційна енергія; одноступеневий тепловий насос; двоступеневий тепловий насос; коефіцієнт трансформації теплоти; опалювальна навантаження; ефективність.

DOI: http://dx.doi.org/10.15673/ret.v53i1.539

(C) The Author(s) 2017. This article is an open access publication

This work is licensed under the Creative Commons Attribution 4.0 International License (CC BY) http://creativecommons.org/licenses/by/4.0/

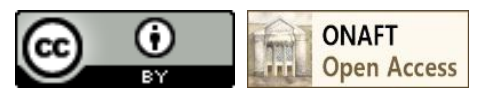

\section{Introduction}

Unlike fossil fuels, the unconventional geothermal energy resource is not limited. Therefore, one of the main trends as to the replacement of traditional and upgrading of existing heat supply systems consists in the transition to a low-temperature heating system based on the heat pump plants (HPP) using groundwater thermal energy [1, 
2]. To implement the heat transformation processes at HPP various working bodies are applied, but not always their thermodynamic and thermal properties meet the heating systems requirements, especially in climates where the atmospheric temperature is low enough [3]. As the thermal load increases the heat potential augments and its maximum value implies also the maximum heat carrier temperature in the heating system. Therefore, during periods of highest temperature gap between the low potential heat source and the heating systems' heat carrier (especially in the sever climatic regions) to cover the full heating load, the two-stage HPP are used. Analysis of recent research and publications. In recent years, there arises the need to improve the HPP efficiency [4].

\section{General material}

The article deals with a promising concept of the twostage heat pump system (Figure 1), useful for heating systems with low potential heat source $[5,6]$.

This scheme operating principle is following: water from the heat generator 9 reaches the pump 8, delivering it for heating to the capacitors 6 and 7, serially connected to the water feeding system. The cooling zone condensers separating superheated steam from the condensation zone thus provide the countercurrent working fluid - and heated water circulation therefore enabling the temperature increase of the heated water that leaves the condenser concurrently reducing the energy loss from irreversible heat exchange. The primary stage capacitor 7 is heating the water from the temperature $t_{\mathrm{s} 1}$ to a certain intermediate temperature $t_{\mathrm{i}}$. then the water enters the secondstage capacitor 6 and is heated therein to $t_{s 2}$ temperature. The low potential groundwater heat entering the evaporator 3 is passed to boiling working agent, which vapor at a pressure $P_{0}$ reaches the lower-stage compressor 1 , where it is compressed to a pressure $P_{\mathrm{i}}$, and divided into two streams. One stream flows into the capacitor 7 , wherein during the heat transfer to the heated water it is condensed, and the other reaches the upper-stage capacitor 2 where it is compressed to a pressure $P_{c}$, and passing into the capacitor 6 it heats the carrier fluid from the intermediate temperature to a temperature ts2. Then, the working medium condensation through an expansion valve 5 passes into the condenser 7 , and the total flow of condensate from the capacitor 7 is supplied via the throttle valve 4 to the evaporator [7].

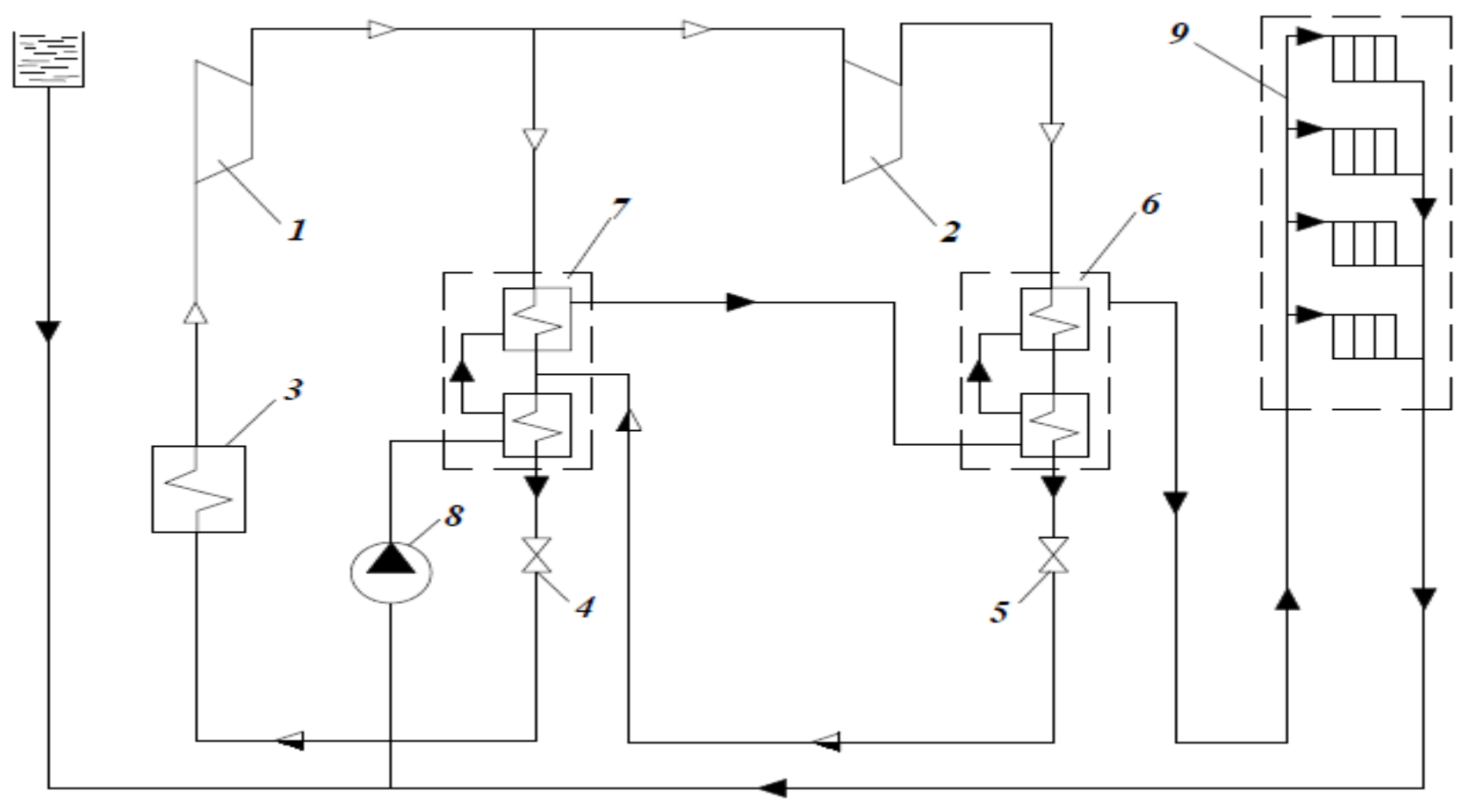

Figure 1 - Two-stage HPP principal diagram

For further comparison of two-stage HPP energy efficiency a heating diagram based on single stage HPP operating with the groundwater energy source is represented (Figure 2), where low-grade heat source (ground water), transmits heat to freon in the evaporator 2, the freon is boiling, and that steam absorbed with compressor 1 , it is compressed. Then the freon is supplied to the water- cooled condenser 3, the water representing a highpotential heat source, which is fed into the heating system 6 , equipped with a pump 5. Upon heat exchanging the freon steam is condensed and in the state of liquid refrigerant through the expansion valve 4 , where its temperature and pressure drop, flows back to the evaporator [1]. 


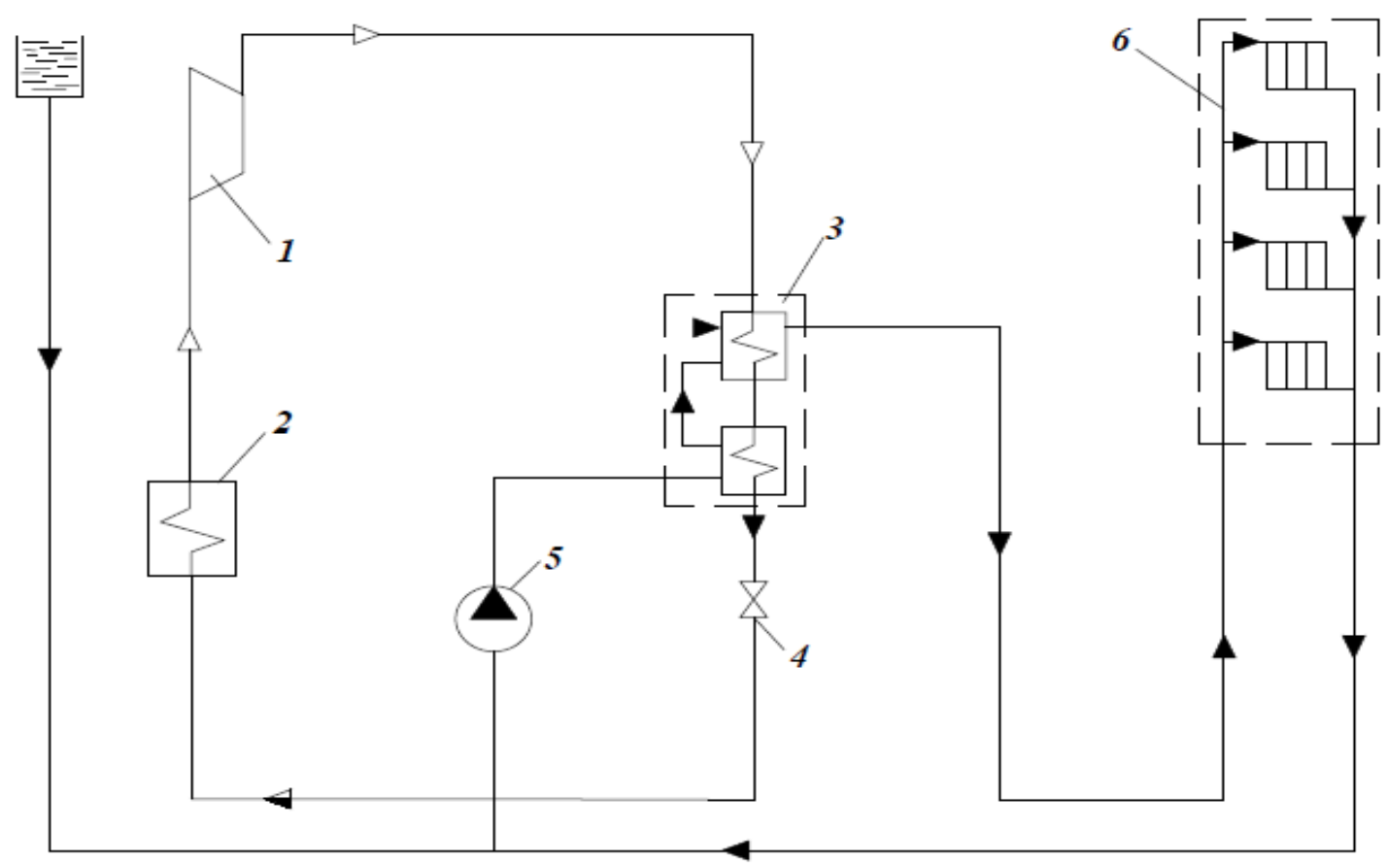

Figure 2 - Single-stage HPP principal diagram

\section{Method of analysis}

The aim of research includes a comparative analysis of the considered two-stages HPP energy efficiency schemes using environmentally friendly refrigerant R152a for heating systems, with low-potential heat source represented by ground water in the temperature range $t_{\mathrm{st} 1}=4 \ldots 12^{\circ} \mathrm{C}$, [8], for a full coverage of the heat load on the heating system when the outdoor temperature $t_{0}=-18^{\circ} \mathrm{C}$.

In order to analyze the considered two-stages HPP energy efficiency schemes we shall use the method [1,9], implemented with the auxiliary of the Cool Pack program p, h-diagram (Figure 3, 4) [10].

The freon evaporation temperature $t_{\mathrm{fe}}$, allowing to estimate the enthalpy $h_{1}$ and pressure $P_{0}$ of freon at the evaporator's exit:

where:

$$
t_{f e}=t_{1 p 2}-\Delta t_{e},
$$

$t_{1 \mathrm{p} 2}$ - low-potential heat source temperature, ${ }^{\circ} \mathrm{C}$;

$\Delta t_{\mathrm{e}}$ - temperature drop at the evaporator's exit, $\mathrm{K}$.

The freon condensation temperature $t_{\mathrm{fc}}$, allowing to estimate the enthalpy $h_{3}$ and pressure $P_{c}$ of freon at the evaporator's exit:

where:

$$
t_{\mathrm{fc}}=t_{\mathrm{hp} 2}+\Delta t_{\mathrm{c}}
$$

$t_{\mathrm{hp2}}-$ high-potential heat source temperature at the condenser's exit, ${ }^{\circ} \mathrm{C}$;

$\Delta t_{\mathrm{c}}$ - temperature drop at the condenser's exit, $\mathrm{K}$.

Compressor's adiabatic efficiency [9]:

where:

$$
\eta_{\mathrm{a}}=0,98\left(273+t_{0}\right) /\left(273+t_{\mathrm{fc}}\right)
$$

$t_{0}$ - atmospheric air temperature, ${ }^{\circ} \mathrm{C}$.
Freon enthalpy at the compressor's exit

$$
h_{2 f}=h_{\mathrm{f} 1}+\left(h_{2 \mathrm{a}}-h_{1}\right) / \eta_{\mathrm{a}},
$$

where

$h_{2 a}$ - freon enthalpy upon adiabatic compression completing, kJ/kg. Condenser specific heat load:

$$
q_{\mathrm{c}}=h_{2}-h_{3}
$$

HPP specific heat load:

$$
q_{\mathrm{h} 1}=q_{\mathrm{c}} .
$$

Compression work at the compressor:

$$
I_{\mathrm{cw}}=h_{2}-h_{1} \text {. }
$$

Specific energy consumed by the electric motor:

where:

$$
W=I_{\mathrm{cw}} /\left(\eta_{\mathrm{e} / \mathrm{m}} \eta_{\mathrm{e}}\right),
$$

$\eta_{\mathrm{e} / \mathrm{m}}$ - compressor's electro mechanic efficiency;

$\eta_{\mathrm{e}}$ - electric motor efficiency.

Heat transformation coefficient

$$
\mu=q_{\mathrm{h} 1} / I_{\mathrm{cw}} \text {. }
$$

Freon mass consumption:

where:

$$
G_{\mathrm{fmc}}=Q_{\mathrm{h} 1} / q_{\mathrm{h} 1} .
$$

$Q_{\mathrm{h} 1}-$ HPP heat load, kW.

Electric power consumed by the compressor's drive:

$$
N=W G_{\text {fmc }} .
$$

To analyze the two-stage HPP efficiency (Figure 1) we use the methods [9]. Intermediate compressive pressure

$$
P_{\mathrm{i}}=\left(P_{\mathrm{e}} P_{\mathrm{c}}\right)^{1 / 2} \text {. }
$$




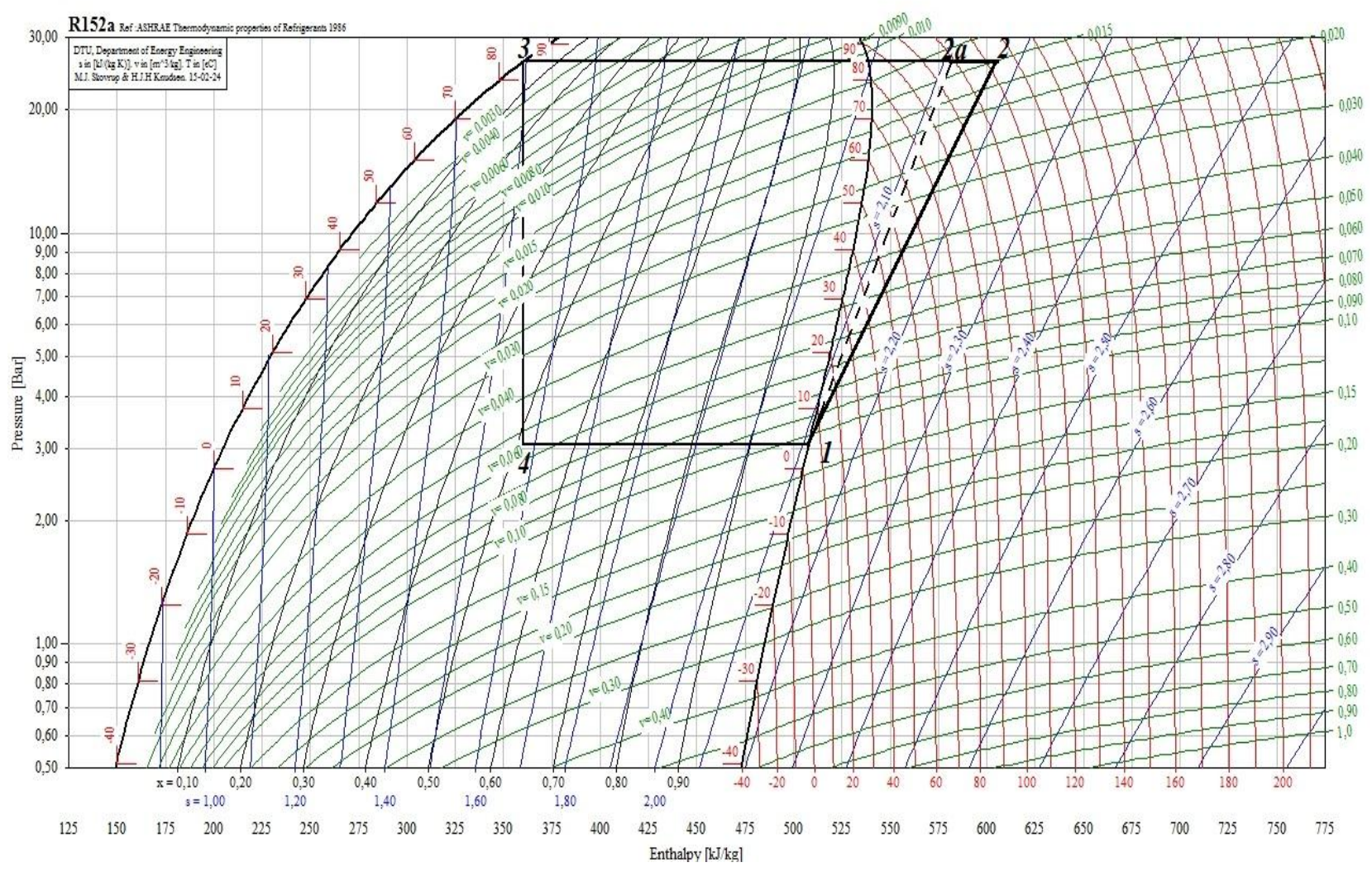

Figure 3-Cycle of single stage HPP operating with ground water energy for heating system at $t_{0}=-18^{\circ} \mathrm{C}$

At two-stages HPP calculation, the freon consumption at the low $G_{\mathrm{fmc}}^{\prime}$ and high $G_{\mathrm{fmc}}^{\mathrm{h}}$ pressure circuits are found from the power balance condition:

where:

$$
G_{\mathrm{fmc}}^{\prime}\left(h_{4}-h_{9}\right)=G_{\mathrm{fmc}}^{\mathrm{h}}\left(h_{4}-h_{8}\right),
$$

$h_{4}, h_{8}, h_{9}$ - enthalpy at the process working points 4,8 , 9, kJ/kg (Fig. 4).

In such a way we obtain the ratio between freon consumption levels at the high $G_{\text {fmc }}^{\text {h }}$ pressure and low $G_{\text {fmc }}^{\prime}$ pressure circuits

where:

$$
G_{\mathrm{fmc}}^{\mathrm{h}} / G_{\mathrm{mc}}^{\mathrm{l}}=\left(h_{4}-h_{9}\right) /\left(h_{4}-h_{8}\right)=(\delta+1) / 1,
$$

$\delta$ - the proportion of freon vapor produced by $1^{\text {st }}$ stage condenser and this one produced by $1^{\text {st }}$ stage compressor.

Enthalpy of freon vapor entering the $2^{\text {nd }}$ stage high pressure compressor:

where:

$$
h_{3}=\left(h_{2}+\delta h_{4}\right) /(1+\delta),
$$

$h_{2}$ - freon enthalpy at the $1^{\text {st }}$ stage compressor exit, $\mathrm{kJ} / \mathrm{kg}$.

Freon consumption at the high pressure circuit:

where:

$$
G_{\mathrm{fmc}}^{\mathrm{h}}=Q_{\mathrm{h} 1} /\left(h_{5}-h_{7}\right) \text {, }
$$

$h_{5}$ - freon enthalpy at the $2^{\text {nd }}$ stage compressor exit, $\mathrm{kJ} / \mathrm{kg}$.

Freon consumption at the low pressure circuit:

$$
G_{\mathrm{fmc}}^{\prime}=G_{\mathrm{fmc}}^{\mathrm{h}} /(1+\delta) \text {. }
$$

Mechanical energy consumed by the $1^{\text {st }}$ and $2^{\text {nd }}$ stage compressor drives:

$$
N_{\mathrm{m} \Sigma}=G_{\mathrm{fmc}}^{\mathrm{h}}\left(h_{5}-h_{3}\right)+G_{\mathrm{mc}}^{\mathrm{l}}\left(h_{2}-h_{1}\right) .
$$

Electrical energy consumed by the compressor drive:

$$
N=N_{\mathrm{m} \Sigma} / \eta_{\mathrm{e}} / \mathrm{m} \text {. }
$$

Heat transformation coefficient:

$$
\mu=Q_{\mathrm{h} 1} / N \text {. }
$$

\section{The results of numerical simulation single-stage and two-stages hpp operating with ground water energy}

To calculate the power efficiency of the considered HPP circuits for heat supply system, adopted are the following initial data of that system thermal scheduling of $95 . . .50^{\circ} \mathrm{C}$ with cutoff at $80^{\circ} \mathrm{C}$ :

- ground water temperature at the evaporator's entrance HPP $t_{\text {st } 1}=4 \ldots 12^{\circ} \mathrm{C}$;

- ground water temperature at the evaporator's exit $\mathrm{HPP} \mathrm{t}_{\mathrm{Ip} 2}=1 . . .9^{\circ} \mathrm{C}$;

- temperature drop at the heat exchangers' exit $\Delta_{\mathrm{te}}=5 \mathrm{~K}, \Delta \mathrm{t}_{\mathrm{c}}=5 \mathrm{~K}$;

- compressor's electromechanical efficiency $\eta_{\mathrm{e} / \mathrm{m}}=0,95$;

- HPP heat load $Q_{\mathrm{hl}}=502 \mathrm{~kW}$ (5-fllors building for 60 apartments).

- atmospheric air temperature $t_{0}=-18^{\circ} \mathrm{C}$;

- heating intrabuilding devices - sectional radiators. 


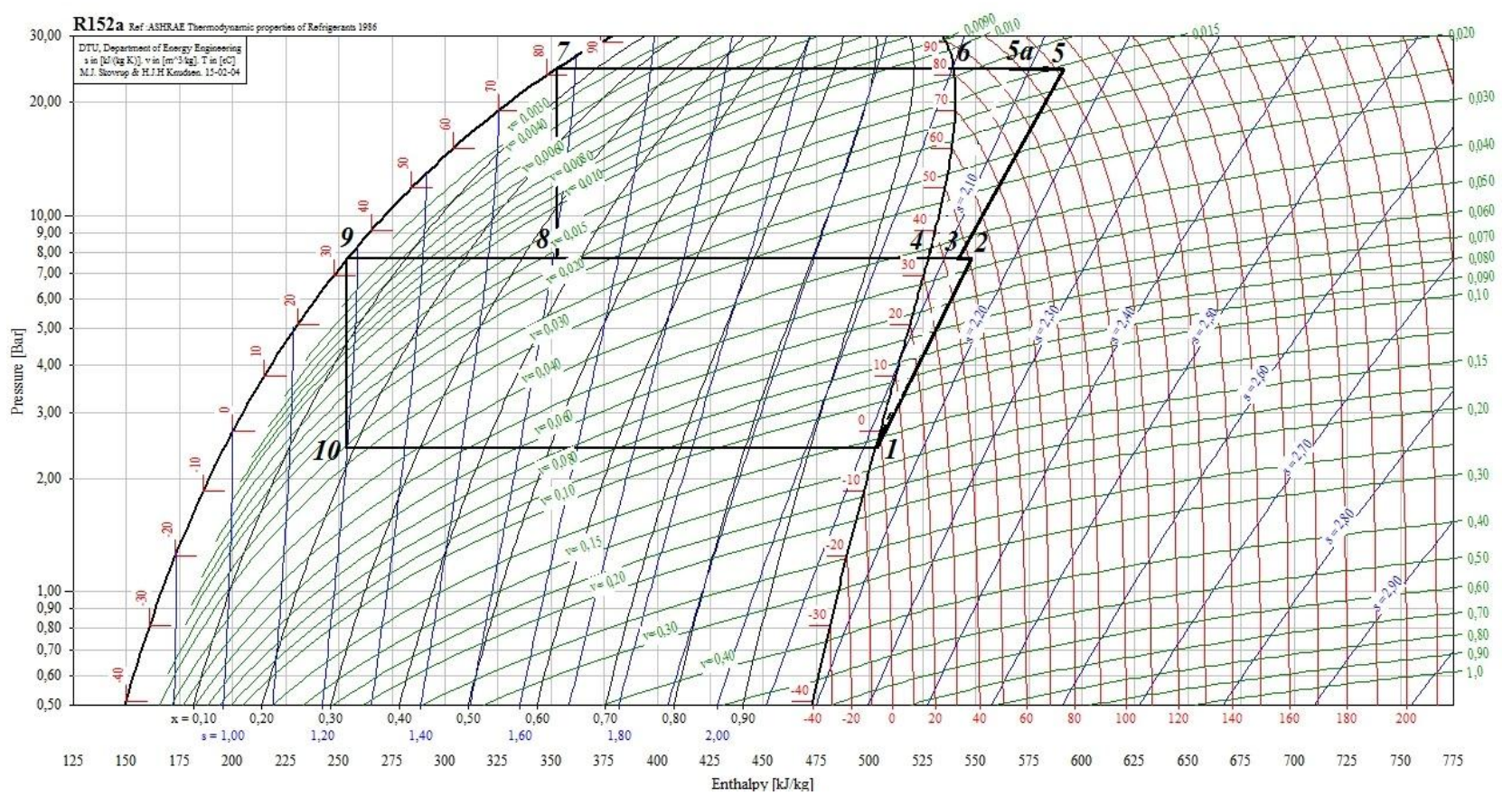

Figure 4-Cycle of two-stage HPP operating with ground water energy to supply for heating system at $t_{0}=-18^{\circ} \mathrm{C}$

In order to analyze the energy efficiency of the considered HPP circuits application for heat supply system using ground water as low-potential heat source, ceteris paribus the following values have been obtained (Table 1, Figure 5,
6). As the refrigerant selected is the environmentally friendly agent R152a, convenient for enhancing the HPP efficiency due to its thermal properties [3].

Table 1 - HPP power efficiency parameters

\begin{tabular}{|c|c|c|c|c|}
\hline \multirow{2}{*}{$T_{\text {st1 }},{ }^{\circ} \mathbf{C}$} & \multicolumn{2}{|c|}{$\mathbf{k W}$} & \multicolumn{2}{c|}{} \\
\cline { 2 - 5 } & Single-stage HPP & Two-stage HPP & Single-stage HPP & Two-stage HPP \\
\hline 10 & 221,2 & 174,7 & 2,387 & 2,871 \\
\hline 14 & 208,7 & 168,9 & 2,530 & 2,971 \\
\hline 18 & 195,7 & 155,4 & 2,698 & 3,228 \\
\hline 22 & 183,2 & 149,4 & 2,883 & 3,359 \\
\hline 26 & 170,7 & 137,1 & 3,093 & 3,659 \\
\hline
\end{tabular}

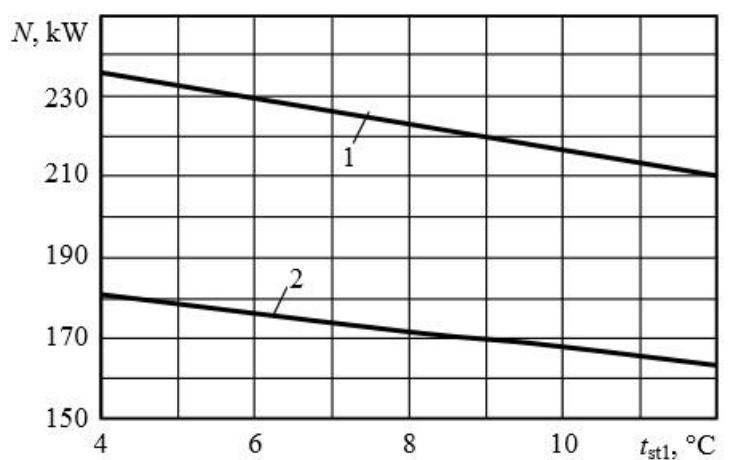

Figure 5-Dependence between the electric power consumption $N$ and the ground water temperature $t_{s t 1}$ at the evaporator entrance for single-stage (1) and two-stage (2) HPP

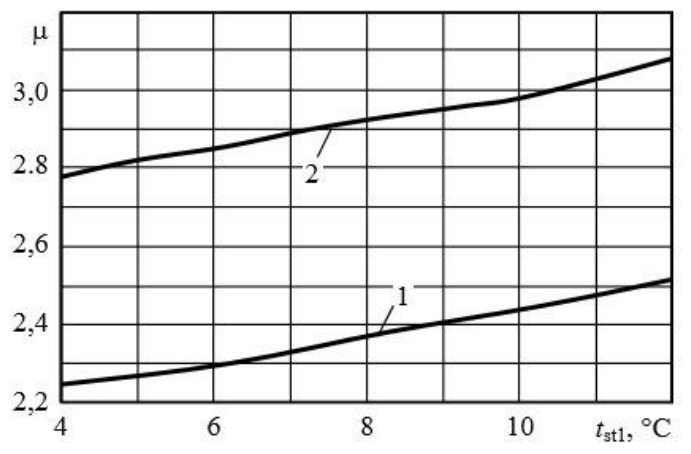

Figure 6-Dependence between the heat supply system transformation coefficient $\mu$ and the ground water temperature $t_{s t 1}$ at the evaporator entrance for single-stage (1) and two-stage (2) HPP 
The analysis of heat supply systems' parameters (Table 1) using HPP when temperatures schedule $95 \ldots 50^{\circ} \mathrm{C}$ with cutoff at $80^{\circ} \mathrm{C}$ operating the low-potential heat source of ground water $t_{\text {st } 1}=4 \ldots 12^{\circ} \mathrm{C}$ does evidence that the smaller is the temperature drop between the low-potential heat source and the municipal system heat carrier, the higher is the HPP efficiency.

Therefore, from power viewpoint, more efficient is a two stages HPP based heat supply system, that is illustrated with the heat transformation coefficient $\mu$, which average increase is $19 \%$ when compared to a system based onto a single-stage HPP at the expense of lower electric power quantity consumed by compressors' drive $N$. In other words, two-stages HPP allow producing more heat energy for the heat supply system under the same electric power consumption level. Therefore, to satisfy completely the heat loads of heat supply system, especially at the environmental temperatures below $t_{0}==-18^{\circ} \mathrm{C}$, essential is to apply alternative heat supply systems using two-stage HPP.

\section{The results of numerical simulation of hpp at ground water inflow from the borehole for various heating intrabuilding devices - sectional radiators and underfloor heating}

Fig. 7 shows a diagram of inflow of groundwater the vertical borehole. The borehole must be provided with special suction pump destined to supply ground water to the evaporator HPP. Groundwater get into the vertical borehole through the water permeable in the radial direction along the entire height of the borehole. The height of the aquifer is equal $H_{0}$. After starting pumping the groundwater level begins to drop and the free surface and the free surface take the form of so-called depression funnel [3].

Volumetric flow of groundwater, $\mathrm{m}^{3} / \mathrm{s}$ [9]:

$$
V_{\mathrm{w}}=1,36 k\left(H_{0}^{2}-h_{\mathrm{bor}}{ }^{2}\right) / \lg \left(R_{\mathrm{bor}} / r_{\mathrm{bor}}\right) \text {, }
$$

where:

$k$ - filtration coefficient, $\mathrm{m} / \mathrm{s}$;

$H_{0}$ - depth of the borehole relative to the natural groundwater level, $\mathrm{m}$;

$r_{\text {bor }}$ - borehole radius, $\mathrm{m}$;

$R_{\text {bor }}$ - range of radius, where the influence of borehole is considerable, $\mathrm{m}$.

Heat load from the groundwater flow in the evaporator of the heat pump

where:

$$
Q_{0}=G_{\mathrm{w}} c_{\mathrm{p}} \Delta t
$$

$c_{\mathrm{p}}$ - heat capacity of the ground water, $\mathrm{kJ} /(\mathrm{kg} \cdot \mathrm{K})$;

$\Delta t$ - difference between the temperature of the ground water at the inlet and outlet of the evaporator HPP, $\mathrm{K}$

$G_{\mathrm{w}}-$ mass flow rate of groundwater, $\mathrm{kg} / \mathrm{s}$

$$
G_{w}=V_{w} \rho_{w}
$$

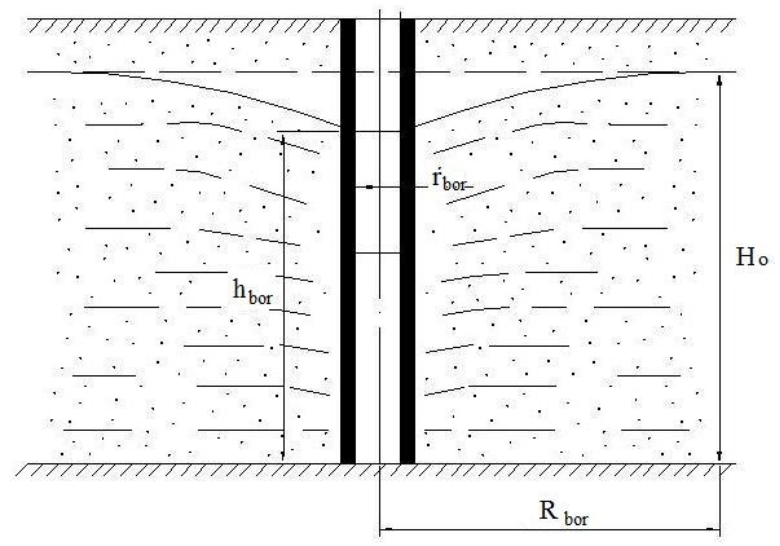

Figure 7-Scheme of inflow of ground water to the vertical borehole

Heat power of the evaporator of single-stage HPP [10]

$$
Q_{0}=G_{\mathrm{fmc}}\left(h_{1}-h_{4}\right), \mathrm{kW} \text {. }
$$

Heat power of the evaporator of two-stages HPP [11]

$$
Q_{0}=G_{\mathrm{fmc}}^{\prime}\left(h_{1}-h_{10}\right), \mathrm{kW} \text {. }
$$

Electrical energy consumed by the pump drive pumping out the ground water from a borehole and providing a required pressure to supply water to the evaporator:

$$
N_{\text {bor }}=V_{\mathrm{w}} \Delta P /\left(1000 \eta_{\mathrm{k}}\right), \mathrm{kW}
$$

where:

$\Delta P$ - pressure drop depending on depth of the borehole $H_{0}, \mathrm{~Pa}$;

$\eta_{\mathrm{k}}$ - electric motor efficiency of pump.

The corresponding results of numerical simulation of energy efficiency of TNI heating systems with two intrahouse heating devices (sectional radiators and floor heating) were obtained (Figure 8, 9).

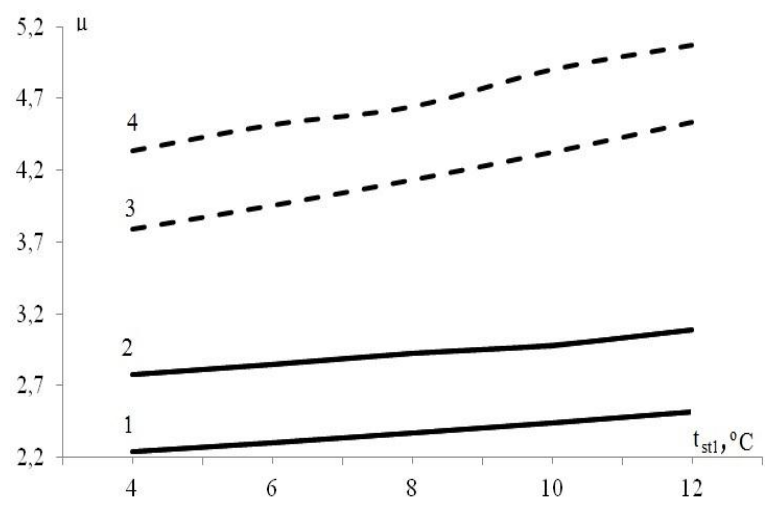

Figure 8 - Dependence between the transformation coefficient $\mu$ and the ground water temperature $t_{\mathrm{st} 1}$ at the evaporator entrance:

1 - single-stage HPP with section radiators;

2 - two-stage HPP with section radiators;

3 - single-stage HPP with underfloor heating;

4-two-stage HPP with underfloor heating 


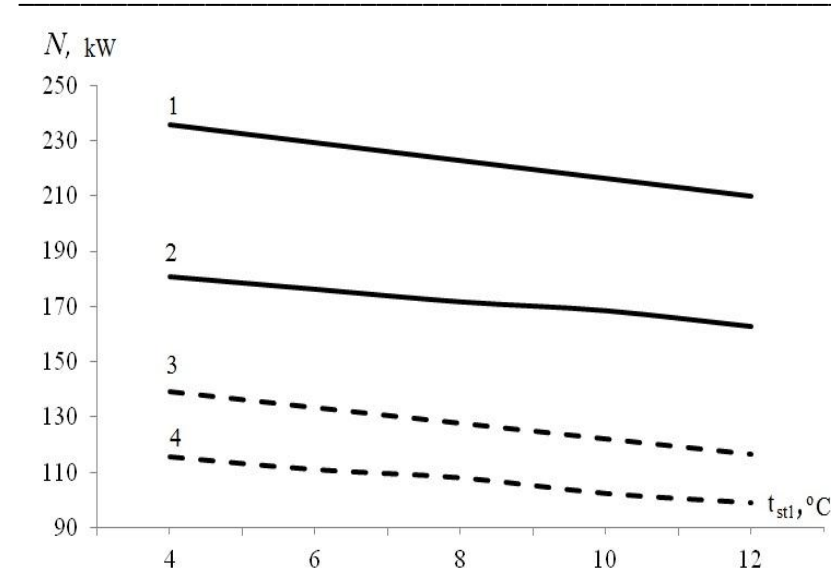

Figure 9 - Dependence between the electrical energy consumed by the pump drive $N$ and the ground water temperature $t_{\mathrm{st} 1}$ at the evaporator entrance:

1 - single-stage HPP with section radiators;

2 - two-stage HPP with section radiators;

3 - single-stage HPP with underfloor heating;

4-two-stage HPP with underfloor heating
In order to maintain the required heat output of the evaporator HPP and saving electrical energy used by the pump drive pumping out the ground water from the borehole the rational approach to the placement of equipment must be used.

The values of required depth of the borehole $H_{0}$ providing the required volume flow rate of water flowing into the evaporator of HPP and total electric energy consumed by the pump $N_{\text {bor }}$ are shown in the Table 2.

The calculations are made for the clay when $k=$ $=10^{6} \mathrm{~m} / \mathrm{s} ; r_{\text {bor }}=0,15 \mathrm{~m} ; R_{\text {bor }}=100 \mathrm{~m} ; h_{\text {bor }}=10 \mathrm{~m}$.

\section{Conclusions}

Results of numerical simulation for HPP heating systems in the temperature chart $95 \ldots 50^{\circ} \mathrm{C}$ with a temperature of cutting $80^{\circ} \mathrm{C}$ by using low-grade heat source (ground water) with temperatures $\mathrm{t}_{\mathrm{st} 1}=4 \ldots 12^{\circ} \mathrm{C}$ shows that the less is temperatures drop between the lowpotential heat source and the coolant being supplied to the heating circuit, the higher is HPP efficiency.

Table 2 - Performance indicators depending on the temperature of the ground water

\begin{tabular}{|c|c|c|c|c|c|c|c|}
\hline \multirow{2}{*}{ Number of boreholes } & \multirow{2}{*}{ HPP } & \multirow{2}{*}{ Values } & \multicolumn{5}{|c|}{ Ground water temperature at the evaporator's entrance of HPP $\mathrm{t}_{\mathrm{st1} 1},{ }^{\circ} \mathrm{C}$} \\
\hline & & & 4 & 6 & 8 & 10 & 12 \\
\hline \multirow{12}{*}{ One borehole } & 1 & $Q_{0}, \mathrm{~kW}$ & 277,7 & 283,9 & 290,0 & 296,1 & 302,2 \\
\hline & 2 & $Q_{0}, \mathrm{~kW}$ & 330,0 & 334,3 & 338,7 & 341,7 & 347,2 \\
\hline & 3 & $Q_{0}, \mathrm{~kW}$ & 369,4 & 374,9 & 380,4 & 385,8 & 391,1 \\
\hline & 4 & $Q_{0}, \mathrm{~kW}$ & 391,7 & 396,1 & 399,0 & 404,5 & 407,7 \\
\hline & 1 & $H_{0}, \mathrm{~m}$ & 214 & 216 & 219 & 221 & 223 \\
\hline & 2 & $H_{0}, \mathrm{~m}$ & 233 & 235 & 236 & 237 & 239 \\
\hline & 3 & $H_{0}, \mathrm{~m}$ & 247 & 249 & 250 & 252 & 254 \\
\hline & 4 & $H_{0}, \mathrm{~m}$ & 254 & 256 & 256 & 258 & 259 \\
\hline & 1 & $N_{\text {bor, }}, \mathrm{kW}$ & 55,5 & 57,3 & 59,2 & 61,1 & 63,0 \\
\hline & 2 & $N_{\text {bor, }}, \mathrm{kW}$ & 71,9 & 73,3 & 74,7 & 75,7 & 77,5 \\
\hline & 3 & $N_{\text {bor, }}, \mathrm{kW}$ & 85,1 & 87,0 & 88,9 & 90,8 & 92,7 \\
\hline & 4 & $N_{\text {bor, }}, \mathrm{kW}$ & 92,9 & 94,5 & 95,5 & 97,5 & 98,7 \\
\hline \multirow{12}{*}{ Two boreholes } & 1 & $Q_{0}, \mathrm{~kW}$ & 277,7 & 283,9 & 290,0 & 296,1 & 302,2 \\
\hline & 2 & $Q_{0}, \mathrm{~kW}$ & 330,0 & 334,3 & 338,7 & 341,7 & 347,2 \\
\hline & 3 & $Q_{0}, \mathrm{~kW}$ & 369,4 & 374,9 & 380,4 & 385,8 & 391,1 \\
\hline & 4 & $Q_{0}, \mathrm{~kW}$ & 391,7 & 396,1 & 399,0 & 404,5 & 407,7 \\
\hline & 1 & $H_{0}, \mathrm{~m}$ & 151 & 153 & 155 & 156 & 158 \\
\hline & 2 & $H_{0}, \mathrm{~m}$ & 165 & 166 & 167 & 168 & 169 \\
\hline & 3 & $H_{0}, \mathrm{~m}$ & 174 & 176 & 177 & 178 & 180 \\
\hline & 4 & $H_{0}, \mathrm{~m}$ & 180 & 181 & 181 & 183 & 183 \\
\hline & 1 & $N_{\text {bor, }}, \mathrm{kW}$ & 39,2 & 40,5 & 41,9 & 43,2 & 44,5 \\
\hline & 2 & $N_{\text {bor, }}, \mathrm{kW}$ & 50,8 & 51,8 & 52,8 & 53,5 & 54,8 \\
\hline & 3 & $N_{\text {bor, }}, \mathrm{kW}$ & 60,2 & 61,5 & 62,9 & 64,2 & 65,6 \\
\hline & 4 & $N_{\text {bor, }}, \mathrm{kW}$ & 65,7 & 66,8 & 67,6 & 68,9 & 69,8 \\
\hline \multirow{12}{*}{ Three boreholes } & 1 & $Q_{0}, \mathrm{~kW}$ & 277,7 & 283,9 & 290,0 & 296,1 & 302,2 \\
\hline & 2 & $Q_{0}, \mathrm{~kW}$ & 330,0 & 334,3 & 338,7 & 341,7 & 347,2 \\
\hline & 3 & $Q_{0}, \mathrm{~kW}$ & 369,4 & 374,9 & 380,4 & 385,8 & 391,1 \\
\hline & 4 & $Q_{0}, \mathrm{~kW}$ & 391,7 & 396,1 & 399,0 & 404,5 & 407,7 \\
\hline & 1 & $H_{0}, \mathrm{~m}$ & 124 & 125 & 126 & 128 & 129 \\
\hline & 2 & $H_{0}, \mathrm{~m}$ & 135 & 136 & 136 & 137 & 138 \\
\hline & 3 & $H_{0}, \mathrm{~m}$ & 142 & 144 & 145 & 146 & 147 \\
\hline & 4 & $H_{0}, \mathrm{~m}$ & 147 & 148 & 148 & 149 & 150 \\
\hline & 1 & $N_{\text {bor, }}, \mathrm{kW}$ & 32,0 & 33,1 & 34,2 & 35,3 & 36,4 \\
\hline & 2 & $N_{\text {bor, }}, \mathrm{kW}$ & 41,5 & 42,3 & 43,1 & 43,7 & 44,8 \\
\hline & 3 & $N_{\text {bor }}, \mathrm{kW}$ & 49,1 & 50,2 & 51,3 & 52,4 & 53,5 \\
\hline & 4 & $N_{\text {bor, }}, \mathrm{kW}$ & 53,6 & 54,6 & 55,2 & 56,3 & 57,0 \\
\hline
\end{tabular}

Notes: 1 - single-stage HPP with section radiators; 2 - two-stage HPP with section radiators; 3 - single-stage HPP with underfloor heating; 4 - two-stage HPP with underfloor heating. 
By calculation, it was determined that more efficient is the heating system based onto low-potential groundwater heat source using the two-stage HPP, rather than a system based onto single-stage HPP that is demonstrated with average productivity increase of $19 \%$, as evidenced by the heat transformation coefficient $\mu$. The two stages HPP can almost 1,3 times reduce the average energy consumption, that represent their indisputable advantage when compared to single stage installations. Thus, the conventional heat supply can be replaced by alternative methods based on the two stage HPP use. This is of high actuality for the climatic conditions, when necessary is to completely cover the heating load, particularly at ambient temperature below $t_{0}=-18^{\circ} \mathrm{C}$. The use of two stages heat pump allows to increase the amount of heat for heating system and consumed electrical energy.

Results of numerical simulation shows that improving efficiency of HPP is possible by using underfloor heating instead traditional sectional radiators. This result is achieved through lower temperature coolant supplied to the intrahouse system, thereby reducing the power consumption by the compressor drive for compression of refrigerant to the condensing pressure. This is because the underfloor heating system cowers the whole surface of the floor, and thus, the heat transfer occurs from the larger surface at relatively less than low temperature.

In addition, to maintain the required evaporator capacity must be rational distribution and the amount of intake boreholes. For example, using less than three deep wells compared with one deep borehole can be reduced energy consumption by 1.7 times, resulting in faster payback HPP.

\section{References}

1. Denysova, A. E., Bodnar, I. A., Buhkalo, S. I. (2014). Analysis of power efficiency of ground-water heat pumps.
Bulletin of National Technical University "KhPI": Innovation researches in students' scientific work, 16, 36-44.

2. Tarasova, V. A., Kharlampidi, D. Kh. and Sherstyuk, A. V. (2011). Modeling of heat cooperative modes of soil heat exchangers and heat pumps. Eastern-European Journal of Enterprise Technologies, 5(8), 34-40.

3. Denysova, A. E., Bodnar, I. A., Buhkalo, S. I. (2014). The use of ozone-safe in heat pump plants with use of heat of ground waters. Integrated Technologies and Energy Saving, 2, 71-76.

4. Badescu, V. (2007). Economic aspects of using ground thermal energy for passive house heating. Renewable Energy, 32(6), 895-903.

5. Denysova A. E., Mazurenko A. S. (2006) Integrated alternate system of thermal consumption Proc. Proc. of 15th Int. Conference World sustainable energy days, Wels, Austria, 1275.

6. Denysova A. E., Mazurenko A. S. (2008) Heat pump unit for heat and water supply at base of renewable energy. Proc. of International conference Energy efficiency of Odessa and IFS future. Odessa, 21 February 1265.

7. Brumbaugh, J. E. (2004). Audel HVAC Fundamentals. Vol. 3, Air-Conditioning, Heat Pumps, and Distribution Systems (4th Ed.). Indianapolis, IN: Wiley.

8. Volkov, M. M., Mikheev, A. L. and Konev, K. A. (1989). Gas Engineers Handbook (2nd Ed.). Moscow: Nedra.

9. Sultanguzin, I. A. and Potapova, A. A. (2012). Hightemperature high power heat pumps for a heat supply. Industrial Kazakhstan, 6, 41-44.

10. Maljarenko, V. A., Jakovlev, A. I. (2007). Thermodynamic bases of calculation of vapor compression heat pumps. Energy Saving. Power Engineering. Energy Audit, 7, 33-47.

Received 02 December 2016 Approved 07 February 2017 Available in Internet 17 March 2017 